\title{
Physical and biological variables affecting seabird distributions during the upwelling season of the northern California Current
}

\author{
David G. Ainley ${ }^{a^{*}}$, Larry B. Spear ${ }^{a}$, Cynthia T. Tynan ${ }^{b}$, John A. Barth ${ }^{\mathrm{c}}$, Stephen D. \\ Pierce $^{c}$, R. Glenn Ford ${ }^{d}$, Timothy J. Cowles ${ }^{c}$, \\ ${ }^{a}$ H.T. Harvey \& Associates, 3150 Almaden Expressway, Suite 145, San Jose CA 95118 \\ ${ }^{b}$ Department of Physical Oceanography, Woods Hole Oceanographic Institution, Woods \\ Hole, MA 02543 \\ ${ }^{c}$ College of Oceanic and Atmospheric Sciences, Oregon State University, Corvallis, OR \\ 97331 \\ ${ }^{d}$ R.G. Ford Consulting, Wiedler Street, Portland, OR 97232 \\ * Corresponding author. Email address: dainley@penguinscience.com
}

\begin{abstract}
As a part of the GLOBEC-Northeast Pacific project, we investigated variation in the abundance of marine birds in the context of biological and physical habitat conditions in the northern portion of the California Current System (CCS) during cruises during the upwelling season 2000. Continuous surveys of seabirds were conducted simultaneously in June (onset of upwelling) and August (mature phase of upwelling) with ocean properties quantified using a towed, undulating vehicle and a multi-frequency bioacoustic instrument $(38-420 \mathrm{kHz})$. Twelve species of seabirds contributed $99 \%$ of the total community density and biomass. Species composition and densities were similar to those recorded elsewhere in the CCS during earlier studies of the upwelling season. At a scale of 2-4 km, physical and biological oceanographic variables explained an average of $25 \%$ of the variation in the distributions and abundance of the 12 species. The most important explanatory variables (among 14 initially included in each multiple regression model) were distance to upwelling-derived frontal features (center and edge of coastal jet, and an abrupt, inshore temperature gradient), sea-surface salinity, acoustic backscatter representing various sizes of prey (smaller seabird species were associated with smaller prey and the reverse for larger seabird species), and chlorophyll concentration. We discuss the importance of these variables in the context of what factors may be that seabirds use to find food. The high seabird density in the Heceta Bank and Cape Blanco areas indicate them to be refuges contrasting the low seabird densities currently found in most other parts of the CCS, following decline during the recent warm regime of the Pacific Decadal Oscillation.
\end{abstract}

Key Words. California Current, primary productivity, bioacoustics, seabird abundance, seabird foraging, upwelling fronts. 


\section{Introduction}

The avifauna of the California Current System (CCS), a trophically rich area (Glantz and Thompson, 1981), is arguably the best known of any stretch of ocean of comparable size. Numbers and biomass of seabirds have been determined over large portions of the CCS by intensive efforts spanning multiple seasons and years (e.g., Briggs et al., 1987; Hoefer, 2000), with complementary, usually seasonal efforts of smaller portions spanning multiple decades (e.g., Ainley et al., 1995, Odekoven et al., 2001, Hyrenbach and Veit, 2003). Therefore, community structure and composition are well known, and areas of concentration have been identified, as have some of the larger-scale oceanographic features (fronts) to which seabird occurrence patterns are correlated. Also identified have been trends that show short-term (El Nino-Southern Oscillation) and longer-term climatic influences (climate oscillations) (Veit et al., 1997, Ainley and Divoky, 2001). While some of the oceanographic processes that affect seabird abundance and distribution in the CCS have been identified, this area of research has not in the least been exhausted. Indeed, seabird research in the CCS thus far has resorted to easily-obtainable variables, such as depth and sea-surface temperature and salinity, as proxies for more direct factors, such as measures of prey availability, in order to 'explain' occurrence patterns. The resulting consensus among researchers is that seabirds reside where the food is concentrated. The question still remains, however: How do the birds know where this occurs?

Owing to their highly mobile nature and the required high metabolic rates that can be sustained only by frequent feeding seabirds occur primarily in ocean areas, such as the $\mathrm{CCS}$, that are rich in their micronektonic and macro-zooplanktonic prey. Therefore, seabird distributions are good indicators of the abundance in near-surface waters $(<200$ m) of their prey: fish, crustaceans and cephalopods (e.g., Ballance et al., 1997, 2001; Hunt, 1991; Hunt et al., 1991, 1999; Montevecchi, 1993). While most species feed in the upper few meters, the entire water column overlying continental shelves is accessible to deep-diving seabirds, such as loons, cormorants, and auks. On the other hand, the diving species have reduced flight mobility compared to non-divers because adaptations for diving result in a reduction in flight efficiency (Spear and Ainley, 1997a). As a result, divers are constrained to reside in especially rich areas where only a relatively minimal search for prey is required (Ainley, 1977). In regard to prey availability, therefore, these divers could be 'indicator species.'

In general, it is not surprising that the abundance of seabirds is highly correlated with indices of ocean productivity and acoustic indices of prey abundance at the largest spatial scales down to the mesoscale ( $\sim 15-30 \mathrm{~nm}$; Schneider and Duffy, 1985; Schneider and Piatt, 1986; Loggerwell and Hargraeves, 1996). At smaller spatial scales, on the other hand, our understanding of the specific habitat variables that are important to seabirds is much less developed, perhaps because of scientists' relative inability to measure prey abundance in the context of the temporal, vertical and horizontal parameters that affect availability of prey as perceived by the predators. In other words, while the acoustic sampling of micronekton has become well established, often as a function of fish-stock assessments, previous results have not been well integrated for the purposes of understanding the foraging patterns of top-predators in the marine environment (e.g., Swartzman and Hunt, 2000). Indeed, research relating predators to food at small spatial 
scales has been directed mostly toward the understanding of seabirds' responses to ocean fronts, and the fronts' persistence, predictability, and capacity to concentrate energetically-rich prey. These studies have shown that mesoscale and smaller fronts, with which the CCS is richly stocked, are very attractive to seabirds and other top-predators (references above; Fiedler and Bernard, 1987; Hunt et al., 1990, 1998; Spear et al., 2001, and references therein). Successful, direct correlations of seabird occurrence to prey often has involved special circumstances in topographically limited areas (e.g., Russell and Hunt, 1992; Goss et al., 1997; Mehlum et al., 1999).

The recent development of towed sensor arrays that record and integrate oceanographic properties in real time should help immensely in our understanding of why top-trophic predators occur where and when they do in marine systems. In this study we conducted continuous seabird surveys while using a towed array that had several attached instruments, including multi-frequency acoustic sensors, to quantify the physical properties and biotic concentrations in the water column. We believe that ours is the first time in which this combination of instrumentation has been used in the study of occurrence patterns of top-trophic predators, in this case, seabirds (but see also, for mammals, Tyan et al., this volume). A major goal was to understand the extent to which seabirds respond to various physical versus biological features to assess the presence of prey, and ultimately to explain spatial variation in their occurrence (e.g., Ainley et al., 1992, 1993). Specifically, we relate densities of the 12 most abundant species of seabirds to four oceanographic, three geographic (spatial) and five biological variables. Oceanographic variables examined (sea-surface temperature and salinity, thermocline depth and structure) are those shown previously to have a major effect on seabird distributions at sea (e.g. Hoefer, 2000; Oedekoven et al., 2001, Spear et al., 2001; Hyrenbach and Viet, 2003); spatial variables are the predictable front locations in the study area, and biological variables are those representing primary productivity and prey abundance. We tested two hypotheses: 1) that bird distributions were most strongly affected by biological variables, particularly prey abundance, compared to physical variables; and 2) that within-season evolution of the upwelling features (alongshore jet, etc.), as they affected prey distribution, changed locations of the areas of bird concentration .

\section{Methods}

As a part of the GLOBEC-Northeast Pacific (NEP) program, we conducted surveys during two cruises in the upwelling period of 2000: 30 May - 14 June (seasonal onset of upwelling) and 30 July-12 August (mature upwelling). The study area extended from Newport, Oregon $\left(44.6^{\circ} \mathrm{N}\right)$, to Crescent City, California $\left(41.9^{\circ} \mathrm{N}\right)$, from the shore to 150 $\mathrm{km}$ offshore. Within that area, we surveyed a grid of 12 'mesoscale' tracklines approximately 15 nautical miles apart, and two grids of 'fine-scale' tracklines ( 7.5 miles apart) embedded in the northern and southern portions of the larger (mesoscale) GLOBEC-CCS area (Figure 1).

Seabird surveys, described below, were conducted from the $R / V$ New Horizon, which attempted to closely follow the $R / V$ Wecoma, from which the SeaSoar and acoustic arrays were towed. The $R / V$ New Horizon was charged mainly with the task of conducting net tows and other measurements at pre-determined stations, or at interesting 'hot spots', but 
since its cruising speed was greater than that of the $R / V$ Wecoma (slowed in its towing capacity), the $R / V$ New Horizon was able to quickly catch up, thus allowing continuous synoptic sampling. We could not survey from $R / V$ Wecoma due to lack of berthing space, and because the ship's stacks, being forward of the bridge, would have partially blocked our view of the survey corridor. For a given area of ocean, most seabird data were collected often in tandem (and within 12 hours) and never more than 24 hours of the SeaSoar/acoustic data (described below). We did not view this as an acute problem owing to the time and space coherence scales in the northern CCS. As indicated by Barth et al. (2000), the offshore (depth $>\sim 100 \mathrm{~m}$ ) meanders in the region last for weeks to months. Inshore (depth $<\sim 100 \mathrm{~m}$ ), currents throughout the water column and surface temperature and salinity change with the wind forcing on 2-10 day time scales. The deeper $(\sim 50 \mathrm{~m})$ horizontal density, temperature and salinity fronts are more stable. In general, alongshore correlation length scales are much longer than cross-shelf correlation length scales. For instance, Kundu and Allen (1976), using moored velocity data, find alongshore and cross-shelf correlation scales of at least $30 \mathrm{~km}$, i.e. about the same distance as our between-track spacing and 7 times the size of the bins into which we combined our data (see below).

\subsection{Hydrographic and bioacoustic data}

Other oceanographic data were collected using a towed, undulating vehicle known as 'SeaSoar' (Pollard, 1986), cycled rapidly from the surface to depth while being towed at $3.5 \mathrm{~m} \mathrm{~s}^{-1}$ (7 kts). The SeaSoar vehicle was equipped with a Sea-Bird 9/11-plus conductivity-temperature-depth instrument with dual T/C sensors mounted to point forward through a hole in the SeaSoar nose. A WET Labs Flashpak fluorometer, using 490-nm (30 $\mathrm{nm}$ bandpass) excitation and 685-nm detection wavelengths, was used to estimate chlorophyll concentration $\left(\mathrm{mg} \mathrm{m}^{-3}\right)$. The fluorescence signal was calibrated with discrete samples measured by High Pressure Liquid Chromatography (HPLC). Most of the temperature and salinity data were collected by cycling SeaSoar on a bare hydrographic cable from 0 to $120 \mathrm{~m}$ and back to the surface every $4 \mathrm{~min}$. The result was hydrographic data with high spatial resolution $(1.25 \mathrm{~km}$ between along-track surface points, $500 \mathrm{~m}$ between profiles at mid-depth) obtained rapidly (cross-margin sections in 2-10 h and large-area maps in 2-6 d) so that a detailed 'snapshot' of the system could be obtained (and the case for both vessels). Over the continental shelf, SeaSoar was cycled from 0-55-0 m every 1.5 min which resulted in along-track profile spacing of $1 / 3 \mathrm{~km}$ between surface points and $170 \mathrm{~m}$ at mid-depth. In order to sample to greater depths over the continental slope, SeaSoar was also towed using a faired cable cycling from 0-300-0 m every 8 min. Concurrently, data were logged from a hull-mounted Acoustic Doppler Current Profiler (ADCP). Further details of this data set can be found in Barth et al. (in press).

Using time varying lags and an optimized-thermal-mass-correction, the $24-\mathrm{Hz}$ temperature and conductivity data were corrected and used to calculate $24-\mathrm{Hz}$ salinity, and then averaged to yield 1-Hz values (Barth et al., 2000). The final 1-Hz data files contain unfiltered GPS latitude and longitude; pressure; temperature; salinity; density anomaly (sigma $t$ ) computed using the 1980 equation of state; chlorophyll concentration

$\left(\mathrm{mg} \mathrm{m}^{-3}\right)$; date and time-of-day. The 1-Hz SeaSoar CTD data were averaged into 2-db 
vertical bins and into $\sim 4.3$ along-track bins (bin size varied 3-5 km, depending on ship's speed during each 15-min seabird survey). These data were used to compute environmental parameters including thermocline depth and strength, and chlorophyll maximum concentration (Table 1). These data were then integrated with the along-track data for bird densities.

A four-frequency bioacoustics instrument (HTI, Hydroacoustics Technology Inc.) was towed at about $5 \mathrm{~m}$ depth during the SeaSoar surveys and measured acoustic backscatter at 38,120,200 and $420 \mathrm{kHz}$. The acoustic backscatter for $0-100 \mathrm{~m}$ at each frequency, expressed in volts, was averaged into the horizontal bins matching the bird observations. See below and Foote and Stanton (2000) for further details on bioacoustics.

\subsection{Survey protocol and survey effort}

Seabird surveys were conducted continuously during daylight, using a $300 \mathrm{~m}$ wide transect strip. Within that strip, birds were counted that occurred within the $90^{\circ}$ quadrant off the ship's bow that offered the best observation conditions. Two observers were on watch during all survey periods. During the two cruises in 2000, the total surface of ocean scanned was $953.0 \mathrm{~km}^{2}$ over $191 \mathrm{hrs}$ of effort.

For each bird sighted within the survey strip, we noted behavior: resting on the water, feeding or circling over a potential food source, attracted to the ship, or flying in a steady direction. For the latter behavior, we noted flight direction to the nearest $10^{\circ}$. We recorded as attracted individuals only those that approached the ship from the direction included within a $90^{\circ}$ forward transect quadrant extended towards the horizon. Thus, birds that were attracted but which appeared from behind or from the opposite side of the quadrant were not counted. A new transect was started every 15 minutes contiguous with the previous transect.

Environmental data recorded at the start of each transect included the following: position, course, ocean depth, distance to nearest point on the mainland, wind speed and direction (nearest $10^{\circ}$ ) and speed and course of the vessel. Also for each transect, SeaSoar data (described above) were used to determine sea-surface temperature and salinity (SST, SSS), chlorophyll $a$ concentration by depth (from which the chlorophyll maximum and its depth was determined), as well as thermocline and halocline depths and their gradients. These latter depths were each identified as the shallowest inflection point determined from graphs plotting temperature/salinity as a function of depth. Exceptions occurred where there was no inflection point, and in that case thermocline depth was recorded as being at the ocean surface. We measured thermo/halocline gradient as the temperature/salinity difference (nearest $0.1^{\circ} \mathrm{C} / 0.01$ for salinity) between the bottom of the mixed layer (thermo/halocline depth inflection) to $20 \mathrm{~m}$ below the inflection.

Another set of variables used in the modeling was distance to various along- and cross-shelf features. The first, referred to as Feature A, is the inshore boundary of the alongshore upwelling jet as defined by the $5-\mathrm{m}$ deep $11.5^{\circ} \mathrm{C}$ isotherm in May-June and, after the entire system had warmed seasonally, by the $12.0^{\circ} \mathrm{C}$ in July-August. These isotherms were approximately midway in the cross-shelf temperature gradient associated with the alongshore upwelling jet. The remaining two features were defined by dynamic height or geopotential anomaly. Spatially averaged temperature, salinity and pressure data were used to compute this (dynamic height in meters multiplied by the acceleration of gravity) in $\mathrm{J} \mathrm{kg}^{-1}\left(\mathrm{~m}^{2} \mathrm{~s}^{-2}\right)$ relative to $100 \mathrm{db}$. On cruise sections where the SeaSoar 
profiles were shallower than $100 \mathrm{db}$, geopotential anomaly was calculated using the extrapolation technique described by Reid and Mantyla (1976). Feature B, at $2.0 \mathrm{~m}^{2} \mathrm{~s}^{-2}$, corresponded to where cross-shelf gradients in dynamic height relaxed (were markedly less steep) with greater distance from shore; and Feature $C$, at $2.35 \mathrm{~m}^{2} \mathrm{~s}^{-2}$, indicated the center and highest elevation of the equatorward jet.

In addition we obtained readings from four bioacoustic frequencies, as noted above. Given that acoustic backscatter from small zooplankton and micronekton generally increases as the frequency increases (and wavelength decreases; Foote and Stanton, 2000), the organisms detected ranged in size from larger ones (ca. $3.9 \mathrm{~cm}$ for the $38 \mathrm{kHz}$ frequency, perhaps fish) to smaller (ca. $0.4 \mathrm{~cm}$ for the $420 \mathrm{kHz}$ frequency, perhaps large copepods, amphipods, or small euphausiids). The returns recorded for the acoustic backscatter indicate the density of a particular size of prey from which they have bounced. These were recorded by the receiver as negative values ranging mostly from 70 to -90 , and we analyzed these data in that form. It is important to note, therefore, that the less negative a readings the higher is the prey density. We did not see an advantage at this stage in the GLOBEC project to stratify the acoustic data by depth, because analysis of net samples will someday allow identification of targets and perhaps allow modeling to adjust for the diel migration of potential prey. Such modeling would provide additional insight on 'availability' depending upon a seabird's diving capabilities and temporal pattern of foraging.

\subsection{Data analysis}

Observed counts of seabirds recorded as flying in a steady direction were adjusted for the effect of flight speed and direction relative to that of the ship (Spear et al., 1992; Spear and Ainley, 1997b). The effect of such flux is the most serious bias encountered during seabird surveys at sea (Spear et al., in review). Known as random directional movement (as opposed to nonrandom directional movement, which occurs when birds are attracted or repelled from the survey vessel), this problem usually results in density overestimation because most species fly faster than survey vessels; densities of birds that fly slower or at a similar speed as the survey vessel (e.g., storm-petrels), or are flying in the same direction, are usually underestimated (Spear et al., 1992).

We also tested for autocorrelation of density values among the 15-min transects for each seabird species using the "acf" command of S-PLUS (S-PLUS 1997). Of the 12 most abundant species, the densities of the Sooty Shearwater, Common Murre, Cassin's Auklet, and Northern Phalarope were autocorrelated. To eliminate the autocorrelation, it was necessary to bin the 15-min transects into 1-hr segments. Independent variable values used in the regression analyses for these four species were the midpoint values from each 1-hr segment.

We used STATA (Stata Corp., 1995) to examine the relationship between the distributions (bird density) of the 12 most abundant species and all independent variables (see above), including one temporal variable (Julian date), three spatial variables (distance to each of the three fronts), the four oceanographic variables (see Introduction) and five biological variables (chlorophyll concentration and the four acoustic frequencies). We did not use measures of time other than Julian date, because both cruises occurred during the same season (upwelling, and for local species, the breeding 
season). Julian date, however, reflected the evolution of breeding activities (eggs to chicks) and the passage of migratory species, which dominate the avifauna of the CCS (Briggs et al., 1987). Bird densities for each transect (the sample unit) were weighted by surface area of ocean surveyed $\left(\mathrm{km}^{2}\right)$ to control for differences in survey effort per transect.

A multiple regression analysis, using backward and forward procedures, was conducted for each seabird species by initially entering all 14 independent variables together into the model. Using a step-wise procedure, insignificant terms were dropped, one at a time, in order of increasing P-values. Because many terms were correlated (Table 1), importance of some variables were likely masked by others in the initial model. Therefore, we tested for effects of eliminated terms by putting them, one at a time, back into the model. The model was complete when no terms could be added or dropped. In a multiple regression model, any independent variables that test as having a significant relationship with the dependent variable (bird density) are true influences. That is, their effects are independent of those of other independent variables (correlated or not; see below) that also have significant relationships with density, because each independent term included in the model is evaluated while taking into account (controlling for) the effect of each of the other independent variables.

Frequently, two or more independent variables that are significantly correlated and placed together in a regression model will test as insignificant related to the dependent variable even though one or more may be truly related to the latter (i.e., the statistical effect of each of the correlated independent variables will be negated by the other[s]). However, when using a step-wise procedure in which terms are eliminated one at a time, the independent variable with the lower $P$-value is eliminated first, thus, allowing the second, more important variable, to reveal its true relationship. In other cases, independent variables that are correlated can each have a significant, but independent, relationship with the dependent variable. Identification of the true effects of correlated independent variables is the primary benefit gained by the use of multiple regression analysis.

Densities were log transformed to meet assumptions of normality. Nevertheless, the residuals generated in the regressions for some of the seabird species did not meet those assumptions (Skewness/ Kurtosis Test for Normality of Residuals, $P<0.05$ ). Leastsquares regression analysis (ANOVA), however, is a very robust procedure with respect to non-normality (Seber, 1977: chapter 6; Kleinbaum et al., 1988). Yet, while these analyses yield the best linear unbiased estimator in the absence of normally distributed residuals, $P$-values near 0.05 must be regarded with caution (Seber, 1977: chapter 3). Therefore, we accepted significance in regression analyses at $P<0.025$ instead of $P$ $<0.05$.

SeaSoar or HTI data were not available for some of the periods when we conducted seabird surveys (Figure 1). Therefore, it was necessary to delete some of the survey data used in the regression analyses. As a result, our analyses for the affect of physical and biological factors on bird densities (but not population size analyses - see below) included data collected during $138.5 \mathrm{hr}$ (554 15-min transects) of observations over 695.6 $\mathrm{km}^{2}$ of ocean surface (i.e., when all of the observing systems were functioning in concert). 
We used generalized additive models (GAMs; Hastie and Tibshirani, 1990) to estimate population sizes (see Clarke et al. 2003, for details on methodology used in this study) of the more abundant species (see above). We used all survey data for these analyses, including those in which no SeaSoar or acoustic data were available (i.e., 953.0 $\mathrm{km}^{2}$ of survey effort). The bird survey data that lacked corresponding SeaSoar data were used only for estimation of population sizes. Except for the four species with autocorrelated transect densities (see above), the sample unit was one 15-min survey transect. The five variables initially included in each species' GAM were latitude, longitude, ocean depth, distance from land, and distance from largest colony (data from J. Hodder, Oregon Institute of Marine Biology). The later differed among species and was not applicable for non-breeding species.

Principal components analysis (PCA), in combination with Sidak multiple comparison tests, were used to assess differences in habitat selection among the 12 seabird species considered. Only the 15-min transects in which a given species was recorded were analyzed; the total sample size for the 12 species was 1,209. The eight more important variables identified in the multiple regression analyses were considered as the indicators of species' individual habitat affinities, including Feature A, Feature B, sea-surface salinity, chlorophyll maximum concentration, and the four bioacoustic frequencies.

The PC analyses were weighted by $1 / n$ where $n$ was the sample size for a given seabird species. The purpose of this was to control for unequal sample sizes among species and thus give equal importance to each in the statistical outcome. To test for significant differences in habitat affinities among seabird species, we used two one-way ANOVAs. In the first, we tested for differences among the PC1 scores representing the environmental affinities of each species; in the second, we compared PC2 scores among species. We considered differences between two species to be significant if either or both of the PC1 or PC2 scores differed significantly.

\subsection{Summary of the oceanographic climate during this study.}

The oceanographic data provided good examples of flow-topography interaction including the influence of Heceta Bank and Cape Blanco on circulation in the northern portion of this eastern boundary current. See Barth et al. (2003) for a more detailed discussion. Both cruises occurred during what is known as the 'upwelling period' in the CCS (Bolin and Abbott, 1963; Hickey, 1998). During the May-June cruise, periods of strong, both northerly and southerly winds were evident, with corresponding upwelling and downwelling, respectively; during the July-August cruise, winds were consistently from the north, leading to strong upwelling particularly south of Cape Blanco (Figures 1, 2). Early in the upwelling season the upwelling front and jet followed the bottom topography fairly well (Figure 2). There was cold water inshore of the shelfbreak and close to the coast with pockets of elevated chlorophyll concentration (up to $4 \mathrm{mg} \mathrm{m}^{-3}$ ) (Figure 1). The development of eddies and offshore jets was minimally evident, with Features A-C fairly close together and nearshore (Figure 2). There was, however, evidence for a turning of the generally southward flow back toward the coast on the southern side of Heceta Bank $\left(44.0^{\circ} \mathrm{N}\right)$. This "lee" region had slower current velocities and warm oceanic water moved up onto the Bank from the southwest. Later (August), the 
upwelling front and jet had evolved to be more convoluted including major meanders offshore associated with Heceta Bank and Cape Blanco, especially evident in Feature C (center of jet). The presence of warm, offshore water up on the Bank from the southwest was very evident in August, leading to strong surface gradients (Features A and B) in that region and high zooplankton and fish concentrations (Batchelder et al., 2002). High levels of phytoplankton biomass $\left(>10 \mathrm{mg} \mathrm{m}^{-3}\right.$ ) were found over Heceta Bank and near the coast south of Cape Blanco (Figure 1). The large offshore topographically-driven jet near Cape Blanco carried cold, nutrient-rich, high phytoplankton biomass $\left(2-4 \mathrm{mg} \mathrm{m}^{-3}\right)$ away from the coast over $100 \mathrm{~km}$ offshore.

\section{Results}

\subsection{Correlations among habitat variables}

The physical and biological environmental variables were correlated with one another in $65(83 \%)$ of the 78 possible combinations (Table 1). Considering mainly the relationships having $r$-values $>0.4(\mathrm{P}<0.0001)$, for reasons of brevity, the following was indicated: (1) Feature $\mathrm{C}$ (center of jet) moved farther offshore, and SSS and abundance of smaller prey (represented by $>120 \mathrm{kHz}$ backscatter) increased with Julian date, while density of larger prey (38 kHz) decreased with date; (2) SST increased with distance offshore from Features A and B (the latter also were highly correlated); (3) SSS increased with distance inshore from Feature C; (4) thermocline depth and gradient increased, while SSS decreased, with increase in SST; (6) abundance of larger prey (38 kHz) decreased with increase in SSS; (7) backscatter of the two highest frequencies increased in accord with one another.

\subsection{Seabird species composition}

Twelve seabird species made up $99.2 \%$ of the birds recorded during all transects (Table 2).The predominance and order of abundance of these 12 species is well known from past studies of the CCS avifauna (Ainley, 1976; Wiens and Scott, 1976; Briggs et al., 1987; Tyler et al., 1993). Proportionally, composition of each species within the entire avifauna ranged from $56.9 \%$ to $0.5 \%$. Considering species composition based on biomass did not change the pattern all that much. These 12 species are the basis for the analyses, below, that examines habitat relationships.

\subsection{Change in species' abundance over time}

Overall, seabirds were about twice as abundant early compared to later in the study period (Table 3). Considering all species, early density over the shelf, slope (201-2000 $\mathrm{m}$ ), and pelagic habitat ( $>2000 \mathrm{~m}$ ) was, respectively, $51.3 \pm$ (s.e.) 9.7 ( $\mathrm{n}=211$ transects), $40.2 \pm 10.9(\mathrm{n}=179)$, and $9.2 \pm 1.9(\mathrm{n}=24) \mathrm{birds} / \mathrm{km}^{2}$ (Sidak multiple comparisons test, $\mathrm{P}<0.001)$. In comparison, later densities corresponding to these three habitats were 42.3 $\pm 7.5(\mathrm{n}=154), 3.8 \pm 0.6(\mathrm{n}=105)$, and $2.3 \pm 0.4(\mathrm{n}=91)$ birds $\mathrm{km}^{-2}$ (only difference between shelf and slope significant, $\mathrm{P}<0.001)$. Translating these figures to biomass 
density resulted in the following estimates: early, $45.0 \pm 8.5,32.0 \pm 8.8,2.3 \pm 1.2 \mathrm{~kg} \mathrm{~km}^{-2}$ $(\mathrm{P}<0.01)$; and late, $22.3 \pm 2.7,1.7 \pm 0.3,0.4 \pm 0.1 \mathrm{~kg} \mathrm{~km}^{-2}(\mathrm{P}<0.001)$.

The decline in numbers, by about 400,000 birds, was primarily related to the major decrease in Sooty Shearwaters (Table 2,3). Other species exhibiting major declines in abundance were the Common Murre, Black-footed Albatross, Fork-tailed and Leach's storm-petrels, and Rhinoceros Auklet. In contrast, species that increased considerably over time were the Cassin's Auklet and Pink-footed Shearwater, and especially three migrants from the north including the Northern Fulmar and the two species of phalaropes. The increase of the later species did not compensate for the exodus of the six former species that had declined. Most of the decline in numbers occurred over the slope and pelagic habitats.

\subsection{General seabird habitat relationships}

The multiple regression models explained from $10 \%$ to $44 \%$ of the variance in the distributions of the 12 species of seabirds we considered (Table 4). Variables significantly related to densities ranged from 4 to 6 of the possible 14 (15 variables when including distance to colony among resident species) for the Black-footed Albatross, Western Gull, and Rhinoceros Auklet to a maximum of 10-12 for the Common Murre, Northern Fulmar, Pink-footed Shearwater, Leach's Storm-Petrel and Red Phalarope. Oceanographic variables most often significantly related to density were SSS (11 of the 12 species), distance to Feature B and $200 \mathrm{kHz}$ prey backscatter (10 species each), chlorophyll maximum density and $120 \mathrm{kHz}$ prey backscatter ( 9 species each; Table 4 , Figures 1,2).

More specifically, seabird species were nearly equally divided in their preference for high- vs. low-salinity waters (Table 4). Eleven species were significantly associated with one of the three fronts: five with Feature A (Common Murre, Western Gull, Cassin's Auklet and the two phalaropes), four with Feature B (Sooty Shearwater, Northern Fulmar, Pink-footed Shearwater, and Rhinoceros Auklet), and two with Feature C (Black-footed Albatross and Leach's Storm-Petrel).

Among the five species associated with Feature A, the Western Gull, Cassin's Auklet, and Red and Red-necked phalaropes were located primarily on the inshore (cooler, more saline) side; the Common Murre was distributed relatively evenly on both sides (Figures 3, 4). Two of the species (Northern Fulmar and Pink-footed Shearwater) associated with Feature B occurred mostly on the nearshore, cooler, more saline side; the Sooty Shearwater was found in similar abundance on both sides, and the Rhinoceros Auklet tended to occur in greater densities on the offshore, warmer, less saline side. Similarly, the Black-footed Albatross and Leach's Storm-Petrel, both associated with Feature C, occurred more frequently on the offshore, warmer, less saline side.

All but one (Western Gull) of the 7 larger seabird species ( $>500 \mathrm{~g}$ ) were positively associated with backscatter indicating the larger prey $(38 \mathrm{kHz})$; all but one (Western Gull) of these species also were positively associated with the highest frequency. All of the five smaller species ( $<190 \mathrm{~g}$; Cassin's Auklet, storm-petrels, and phalaropes) were positively associated with higher frequency backscatter (indicating small organisms), and three of the smaller species were positively associated with the two larger prey acoustics. 
The only seabird species not positively associated with chlorophyll maximum were the Black-footed Albatross, Rhinoceros Auklet, Leach's and Fork-tailed storm-petrels.

Overall, seabirds preferred waters near the inshore boundary of the upwelling jet, where chlorophyll concentration was high as were densities of micronekton and zooplankton. When considering all 14 variables, those consistently explaining the most variance among the 12 species were biological ones (chlorophyll maximum and the four acoustic variables), although SSS was among the three most important explanatory variables for nine of the 12 species.

\subsection{Comparison of habitat affinities among seabird species}

The first and second PC axes explained $60 \%$ of the variance in habitat use by the 12 seabird species (Table 5). The most important environmental variables on the PC1 axis were Features B and A on the negative side, and $120 \mathrm{kHz}, 200 \mathrm{kHz}$, and $420 \mathrm{kHz}$ acoustic prey backscatter on the positive side of that axis. Thus, the seabirds strongly associated with the fronts (producing a negative regression coefficient, Table 3) appeared on the negative side (Figure 5), and those not associated with the fronts, and selecting the smaller size prey categories, appeared on the positive side. The most important habitat variables on the PC2 axis were the positively-loaded SSS and chlorophyll maximum, the negatively-loaded $38 \mathrm{kHz}$ prey backscatter, and to a lesser extent the negatively-loaded Features A and B (Table 5). Appearance of species on the negative or positive sides of the PC2 axis reflected their responses to those variables. Note that a negative response (see Table 3) to a positively-loaded habitat variable (Table 5) will tend to place the species on the negative side of an axis, although their actual placement was also influenced by other variables with high negative or positive loadings.

\section{Discussion}

Although many studies have examined seabird abundance and distributions in the CCS in relation to physical environmental parameters (e.g. Briggs et al., 1987; Hoefer, 2000; Oedekoven et al., 2001), this is the first to examine the effects of biological variables simultaneously with the former. Indeed, the CCS, as one the world's four most productive (boundary current) ocean systems and host of a highly abundant and diverse seabird community, is especially well suited for a study of the processes and cues used by seabirds when searching for prey.

Thus, separation of the importance of biological from physical features was the primary objective of our study. In the following we integrate and interpret the indications of our results using a chronological perspective for foraging seabirds.

\subsection{Primary factors to which seabirds responded}

First, it is important to note that the patterns discussed below were, indeed, the seabird's direct responses to environmental variables that were independent of these variable's correlations (confounding) with other habitat variables. Seabirds responded most consistently to four parameters, two physical and two biological, all in a positive manner. Physical parameters attracting each seabird species included one of the three 
fronts and SSS; biological factors attracting various species included waters having the maximum chlorophyll concentration and high abundance of prey of various sizes.

\subsection{Seasonality in species' abundance}

The numbers for most species differed greatly between the beginning (late May to early June) and end (late July to early August) of the upwelling season. In fact, the total declined 51\% between June and August, mostly a function of a drop of $74 \%$ of the four most abundant species (murre, Sooty Shearwater, and the two storm-petrels). This pattern appears to be contrary to the findings of Briggs et al. (1987), who showed that, in spite of a major seasonal change in species composition, the overall density of seabirds in the CCS was fairly constant throughout the year. It is not obvious why our results differed. Perhaps it was related to the fact that the Briggs et al. study occurred at the beginning of a warm Pacific Decadal Oscillation (PDO) period, 1976-1998 (Mantua and Hare, 2002), when all populations in the region were robust, as opposed to our study, which occurred at the end of the long warm-phase decline that followed (e.g. Veit et al. 1997). This issue is discussed further below.

Most of the seasonal changes in species' abundance, on the one hand, can be explained in the context of various species' respective natural-history patterns. Many species that nest elsewhere are attracted to the high productivity of the CCS during their non-breeding periods (Ainley, 1976, Briggs et al., 1987, Tyler et al., 1993). Among these species are the Sooty and Pink-footed shearwaters, both of which begin nesting at sites the Southern Hemisphere beginning in the boreal autumn. Also included among seasonal residents are the Northern-Hemisphere breeding Black-footed Albatross (Hawaiian Islands) and Northern Fulmar (Alaska), which are most abundant in the CCS during the boreal winter, and the Red and Red-necked phalaropes (Arctic tundra), which migrate through in April and August. The remaining species nest along the study-area coast, but higher numbers in certain periods probably represent incursions of individuals from populations that nest outside of the study area. For example, the Cassin's Auklet was much more abundant later in the study period, probably as a result of two factors: 1) during spring a large proportion of the population was tending nests on any given day (Table 3 reports only at-sea numbers); and 2) during the post-breeding period, individuals from southern breeding sites probably had moved north into the region (J. Adams, Moss Landing Marine Lab, pers. comm.). In the case of the Common Murre and Rhinoceros Auklet, a portion of their respective populations likely dispersed out of the study area by August, following the period when adults and offspring are released from nest sites. Finally, the higher populations of storm-petrels (especially the Fork-tailed) early in the period likely represented migrants passing through on their way north, or individuals, including nonbreeding subadults, that had wintered in the study area but had not yet moved north.

On the other hand, the results of the multiple regression models demonstrated that Julian date was not an important variable in explaining variation in seabird species' response to environmental variables. This was particularly true for SSS, chlorophyll concentration and prey abundance, although date was correlated with variation of the habitat variables themselves. The result indicates that variation in seabird abundance was strongly affected by ocean properties regardless of phenological aspects of the seabirds' 
respective natural history patterns (e.g., breeding, migration etc.). Further, this result indicated that seabird response to ocean variables was consistent regardless of time period.

Acoustic backscatter at $38 \mathrm{kHz}$ later in the study period was lower than it was at the onset of upwelling, indicating that larger prey (fish) of piscivorous seabirds possibly had declined in the water column. In accord, the overall number of the seven piscivorous species declined by 3.5 times $(71 \%)$ over the study period, when abundance of smaller prey increased. This was in conjunction with a greater than two-fold (54\%) increase in densities of five smaller (planktivorous) seabird species, consistent with increased availability of organisms at lower trophic levels. Whether or not there is a biological link between the decrease in the larger seabirds and fewer small fish, and increase in smaller seabirds with increase in smaller plankton, remains to be determined. The dominant Sooty Shearwater, for one, must leave the study area by August-September in order to reach New Zealand and Tierra del Fuego in time for breeding. Therefore, their departure may be a phenological coincidence rather than a response to the possible reduction in prey. The latter reduction would be consistent with the two- to three-fold declines in abundance of the piscivorous Common Murre and Rhinoceros Auklet, but not with the six-fold increase in Pink-footed Shearwaters (which, actually, were not all that abundant to begin with).

The biomass density estimates by Briggs et al. (1987; see also Tyler et al., 1993) for the northern portion of the CCS (waters off Northern California, including a portion of the GLOBEC study area) in 1980-82 - shelf, slope, and pelagic habitats - were as follows: $55.2 \pm 8.7,10.9 \pm 1.8$, and $\sim 5.0 \mathrm{~kg} \mathrm{~km}^{-2}$ (total $=71.1 \mathrm{~kg} \mathrm{~km}^{-2}$ ). These estimates represent the total for all seasons, which were sampled equally in their study. Our estimates, with the exception of the slope habitat, were similar and resulted in nearly an identical total (May: 45.0, 32.0, and $2.3 \mathrm{~kg} \mathrm{~km}^{-2}$; total $=79.3 \mathrm{~kg} \mathrm{~km}^{-2}$ ). Given that the Sooty Shearwater, by far the most abundant species in the CCS (and which contributes immensely to overall biomass), declined by $90 \%$ in the CCS since 1976 (Veit et al., 1997; Oedekoven et al. 2001; Ainley and Divoky, 2001), our results are surprising. We expected to encounter significantly fewer numbers and biomass than was present, as we have noted in central California studies (e.g., Oedekoven et al., 2001). It is possible that in addition to their overall decline in the CCS, the shearwaters have become more confined to those regions that still provide high food availability. If so, the areas around Cape Blanco and Heceta Bank have apparently retained their importance to seabirds regardless of the apparent overall decline of zooplankton and presumably micronekton in the CCS (Roemmich and McGowan, 1995). The declines are coincident with the warm phase of the PDO.

\subsection{Relationships to physical and biological variables}

An abundant literature details avian response to mesoscale fronts (see Introduction), and, thus, it is not surprising that distance to the inshore upwelling fronts were among the most important variables explaining seabird abundance patterns in the northern CCS. In fact, very close to shore $(\sim 1 \mathrm{~km})$, a habitat we did not effectively sample (due to a high density of commercial fishing gear sets), temperatures generally were coldest $\left(\leq 9^{\circ} \mathrm{C}\right)$. However, the seabirds responded little to SST itself. SSS was a more important physical 
variable, perhaps because seabirds 1) were attracted to the edge of the most recently upwelled (very high salinity, and cold) water occurring with this front (Feature A), but also 2) because abundance of larger prey was higher in low salinity waters such as the detritus rich Columbia River plume in the northern part of the study area (Feature C). Therefore, there were two elements involved in the response to salinity extremes.

Not surprising, also, was the importance of the acoustically estimated abundance of potential prey. When the MOCNESS samples eventually are fully analyzed by other GLOBEC investigators, we should be able to identify prey components and their assortment in the water column (important for surface-foraging birds). The 38 (and 120) $\mathrm{kHz}$ frequency likely indicates small fish, while 420 (and 200) kHz, indicate smaller animals such as copepods and euphausiids. From what is known about the diets of CCS seabirds (e.g. Ainley and Sanger, 1979; Briggs and Chu, 1987), greater importance of the two lowest frequencies was expected for the albatross, shearwaters, Northern Fulmar, Common Murre, and Western Gull. However, the importance of these size classes was not expected for the two phalaropes and Fork-tailed Storm-Petrel, which prey primarily on smaller organisms (but also fish eggs). Nevertheless, the general pattern showing greater importance of lower acoustic frequencies for the larger species of seabirds, and the highest acoustic frequencies for the smaller seabirds, is consistent with expectations. In fact, one MOCNESS tow, done expressly because we encountered a large concentration of Cassin's Auklets, resulted in one of the largest hauls of larval and subadult Thysanoessa spinifera (euphausiids) on the entire cruise (W. Peterson, NMFS, pers. comm.).

Surprising was the direct linkage between eight of the 12 seabird species and the chlorophyll maximum. It has been suggested that seabirds, and mainly those of the order Procellariiformes (albatross and petrels, which include 6 of the 12 species we studied), use olfaction to cue on dimethyl sulfide (DMS; Nevitt, 1999a, Nevitt et al., 1999). Moreover, even avian species not noted for an acute olfactory sense (Bang, 1966), for example pigeons Columba spp., are known to use olfaction in navigation and homing (Wallraff 2004). Experiments have shown that petrels are particularly responsive to DMS, apparently because they have learned that grazers (petrels' prey) are more abundant where the odor of DMS is highest (references below) [Petrels and albatrosses are also attracted to the odors of fish and krill that are torn apart during predation, a process that leaves oil slicks at the surface (Lequette et al., 1989; Nevitt, 1999b, c)]. DMS is released as algal cells are crushed in the process of being grazed (Dacey and Wakeman, 1986; Daly and DiTullio, 1996); however, grazing on microzooplankton that have ingested DMS-containing algae may also increase DMS prevalence (Levasseur et al., 1996). On the other hand, though elevated concentrations of DMS have been associated in some regions with productive plumes (Hatton et al., 1998), blooms (Kwint and Kramer, 1996; Gabric et al., 1999) and upwelling (Anderson et al., 2001), this is not always the case. While some studies report a connection between the release of DMS in the water column and phytoplankton senescence (Kwint and Kramer, 1995), other studies determined that DMS was not well correlated with chlorophyll $a$ concentration (Kwint and Kramer, 1996) or distributions of phytoplankton, microzooplankton or mesozooplankton (Cantin et al., 1996). Given these contradictory findings, and without direct measurements of DMS relative to plankton abundance in this study area, we can only speculate regarding the possible relationship between DMS or related olfactory cues 
and abundance of seabird prey in our study area. Of certainty, however, was the fact that all sizes and taxonomies of CCS seabirds were attracted to areas rich in chlorophyll, yet none of these birds consume it directly.

Having spent most of their year a long way from the CCS, once birds have found highly productive waters, through olfaction perhaps, they could use visual cues to locate actual prey schools (Haney et al., 1992; Nevitt, 1999c). Although it is possible that nonProcellariiform species were attracted also to the sight of other foraging birds (Hoffman et al., 1981; Maniscalco et al., 1998), this idea was not well supported by the PCA analyses showing only weak associations between most species representing the two groups. Unraveling the relationships between chlorophyll density, prey density and predator response may be facilitated by further analysis of net tow and acoustic data. In any case, the response of seabirds to the chlorophyll maximum, if it signals elevated DMS as well, is evidence that seabirds may be searching for mesoscale habitat features that indicate elevated chances for successful foraging, before constraining their search to locating prey.

\subsection{Comparison to other studies}

In the present study we related variation in seabird density at the small scale $(2-4 \mathrm{~km})$ to habitat and prey variables. The regression models achieved an appreciable level of explanatory power among the 12 seabird species (average $=24.5 \%$ ). In a study at a similar scale in the eastern tropical Pacific, but using a larger study area and only physical and temporal variables (e.g., SST, SSS, depth and slope of thermocline, date), Spear et al. (2001) were able to explain just $8.3 \%$ and $20.7 \%$, respectively, of the variance in the abundance of planktivorous and piscivorous avian species. At a spatial scale similar to the present study but with 12 years of data from one season (April-June), a study in the central CCS that considered most of the habitat variables but not the biological ones in the present study, Oedekoven et al. (2001) explained 52-58\% of variance in the abundance of Sooty Shearwater, Common Murre, and Cassin's Auklet. Finally, using broadly spaced surveys over the entire CCS from Washington to Mexico (to $300 \mathrm{~km}$ offshore), but using only distance to the center of thermally-defined fronts (dramatic gradients in SST) as the independent variable at a 4-km scale ( $\mathrm{n}=55$ fronts), Hoefer (2000) was able to explain occurrence variance as follows: Sooty/Pink-footed shearwaters combined (57 \%), Leach's Storm-Petrel (3 \%), phalaropes combined (52\%), Western Gull (85\%), Common Murre (85\%), and Cassin's Auklet (6 \%). The lower consistency in explained variation, compared to results of the present study and that of Oedekoven et al. (2001), is explainable only in that storm-petrels and Cassin's Auklet were not attracted to fronts as measured by Hoefer (2000). The especially high variance explained by Hoefer (2000) for Western Gull and Common Murre, using just one variable (distance to thermal front), is consistent with the importance of that variable for those species in the present study. Hoefer's results may also have been amplified by the sampling of large areas of the outer CCS, most of which is devoid of Western Gulls and murres, and where frequency of fronts is much reduced compared to inshore waters. Thus, there was much more contrast in the larger-scale Hoefer study.

Wiens and Scott (1976) noted a strong stratification of seabird species from the coast outward in waters off Oregon, a phenomenon that we observed as well. As noted above, 
the Western Gull, Cassin's Auklet, two phalarope species, and, to a lesser degree, the Common Murre were found inshore of the most inshore front (Feature A). The two shearwaters, Rhinoceros Auklet, and Northern Fulmar associated with Feature B, slightly farther offshore from Feature A, while the Black-footed Albatross occurred on the seaward side of the most offshore Feature (C). Thus, the deepest diving species (murre, followed by the auklet with medium-diving-depth) by virtue of their position relative to Feature A, were found in the shallowest water, compared to the shallower-diving shearwaters that associated with Feature B. Thus, on the basis of diving capabilities, if exploiting a significant portion of the water column is important, one would expect perhaps the reverse pattern to have occurred (shallowest divers inshore). This is a very interesting pattern that could involve competitive exclusion at one front or another, or energetic constraints (e.g., Ballance et al. 1997). Resolution awaits better understanding of prey depth-distribution that will come when the GLOBEC net-tow and bioacoustic data have been analyzed.

\section{Acknowledgements}

We thank Robert O'Malley for help in collecting and processing the SeaSoar hydrographic data and for calculating the environmental indices used in this analysis. Chuck Alexander assisted in collecting seabird census data. Thanks also to the OSU Marine Technicians, Marc Willis, Linda Fayler, Daryl Swensen and Toby Martin for helping us to collect high-quality data from SeaSoar. The officers and crew of the $R / V$ Wecoma did an outstanding job towing along our mapping grids while avoiding fishing boat traffic and fixed fishing gear; and, likewise, the officers and crew of $R / V N e w$ Horizon ably contributed to the coordinated effort. We are grateful to Jan Hodder for providing location and number of seabirds at colonies relevant to this study. Support from National Science Foundation Grant OCE-0001035, National Oceanic and Atmospheric Administration (NOAA)/Woods Hole Oceanographic Institution-CICOR Grant NA17RJ1223 is gratefully acknowledged. This is contribution number XXX of the U.S. GLOBEC program jointly funded by the National Science Foundation and NOAA Coastal Ocean Program.

\section{References}

Ainley, D. G., 1976. The occurrence of seabirds in the coastal region of California. Western Birds 7, 33-68.

Ainley, D. G., 1977. Feeding methods in seabirds: a comparison of polar and tropical communities in the eastern Pacific Ocean. In: Llano, G. A. (Ed.), Adaptations within Antarctic Ecosystems. Gulf Publ. Co., Houston, pp. 669-685.

Ainley, D. G., Divoky, G. J., 2001. Seabirds: Effects of climate change. In: Steele, J., Thorpe, S., Tarekian, K. (Eds.), Encyclopedia of Ocean Sciences. Academic Press, London, pp. 2669-2677.

Ainley, D. G., Ribic, C. A., Fraser, W. R., 1992. Does prey preference affect habitat choice in Antarctic seabirds? Marine Ecology Progress Series 90, 207-221.

Ainley, D. G., Ribic, C.A., Spear, L. B., 1993. Species-habitat relationships among Antarctic seabirds: a function of physical and biological factors? Condor 95, 806-816. 
Ainley, D. G., Sanger, G. A, 1979. Trophic relationships of seabirds in the northeastern Pacific Ocean and Bering Sea. In: Bartonek, J. C., Nettleship, D. N. (Eds.), Conservation of Seabirds in Western North America. U. S. Fish and Wildlife Service, Wildlife Research Report 11:95-122.

Ainley, D.G., Veit, R. R., Allen, S. G., Spear, L. B., Pyle P., 1995. Variations in seabird numbers in the California Current, 1986-1994. California Cooperative Oceanic Fisheries Investigations, Reports 36, 72-77.

Anderson, T. R., Spall, S. A., Yool, A., Cipollini, P., Challenor, P. G, Fasham, M. J. R., 2001. Global fields of sea surface dimethylsulfide predicted from chlorophyll, nutrients and light. Journal of Marine Systems 30, 1-20.

Ballance, L. T., Ainley, D. G., Hunt, G. L., Jr., 2001. Seabirds: Foraging ecology. In: Steele, J., Thorpe, S., Tarekian, K. (Eds.), Encyclopedia of Ocean Sciences. Academic Press, London, pp. 2636-2644.

Ballance, L. T., Pitman, R. L., Reilly, S. B., 1997. Seabird community structure along a productivity gradient: importance of competition and energetic constraint. Ecology 78, $1502-1518$.

Bang, B. G., 1966. The olfactory apparatus of tube-nosed birds (Procellariiformes). Acta Anatomica 65, 391-415.

Barth, J. A., Pierce, S. D. Smith, R. L., 2000. A separating coastal upwelling jet at Cape Blanco, Oregon and its connection to the California Current System. Deep-Sea Research II 47, 783-810.

Barth, J. A., Cowles, T. J., Pierce, S. D., in press. Mesoscale structure and its seasonal evolution in the northern California Current System. Deep-Sea Research II, this volume.

Batchelder, H., Barth, J. A., Kosro, P. M., Strub, P. T., Brodeur, R. D., Peterson, W. T., Tynan, C. T., Ohman, M. D., Botsford, L. W., Powell, T. M, Schwing, F. B., Ainley, D. G., Mackas, D. L., Hickey, B. M., Ramp, S. R., 2002. The GLOBEC Northeast Pacific California Current Program. Oceanography 15, 36-47.

Bolin, R. L., Abbott, D. P., 1963. Studies on the marine climate and phytoplankton of the central coastal area of California, 1954-60. California Cooperative Oceanic Fisheries Investigations, Reports 9, 23-45.

Briggs, K. T., Tyler, W. B., Lewis, D. B., Carlson, D. R., 1987. Bird communities at sea off California: 1975 to 1983. Studies in Avian Biology 11, 1-74.

Briggs, K. T., Chu, E. W., 1987. Trophic relationships and food requirements of California seabirds: updating models of trophic impact. In: Croxall, J.P. (Ed.), Seabirds: Feeding Ecology and Role in Marine Ecosystems. Cambridge Univ. Press, Cambridge UK, pp. 279-304.

Cantin, G., Levasseur, M., Gosselin, M., Michaud, S., 1996. Role of zooplankton in the meoscale distribution of dimethylsulfide concentrations in the Gulf of St. Lawrence, Canada. Marine Ecology Progress Series 141, 103-117.

Clarke, E. D., Spear, L. B., McCracken, M. L., Borchers, D. L., Marques, F. F. C., Buckland, S. T., Ainley, D. G., 2003. Validating the use of generalized additive models and at-sea surveys to estimate size and temporal trends of seabird populations. Journal of Applied Ecology 40, 278-292.

Dacey, J. W. H., Wakeham, S. G., 1986. Oceanic demthyl sulphide: production during zooplankton grazing on phytoplankton. Science 233, 1314-1316. 
Daly, K. L., DiTullio, G. R., 1996. Particulate dimethylsulfoniopropionate removal and dimethyl sulfide production by zooplantkon in the Southern Ocean. In: Kiene, R. P, Visscher, P. T., Kellor, M. D., Dirst, G. O. (Eds.), Biological and Environmental Chemistry of DMSP and Related Sulfonium Compounds. Plenum Press, NY, pp. 223238.

Fielder, P. C., Bernard, H. J., 1987. Tuna aggregation and feeding near fronts observed in satellite imagery. Continental Shelf Research 7, 871-881.

Foote, K. G., Stanton, T. K., 2000. Acoustical methods. In: Harris, R., Wiebe, P., Lenz, J., Skjoldal, H. R., Huntley, M. (Eds.), ICES Zooplankton Methodology Manual. Academic Press, London, pp. 223-258.

Gabric, A. J., Matrai, P. A., Vernet, M., 1999. Modelling of production and cycling of dimethylsulphide during the vernal bloom in the Barents Sea. Tellus, Series B, Chemical and Physical Meteorology 5, 919-937.

Glantz, M. H., Thompson, J. D. (Eds.), 1981. Resource Management and Environmental Uncertainty: Lesson from Upwelling System Fisheries. Wiley, New York.

Goss, C., Bone, D. G., Peck, J. M., Everson, I., Hunt, G. L., Jr., Murray, A. W. A., 1997. Small-scale interactions between prions Pachyptilla spp. And their zooplankton prey at an inshore site near Bird Island, South Georgia. Marine Ecology Progress Series 154, 41-51.

Haney, J. C., Fristrup, K. M., Lee, D. S. 1992. Geometry of visual recruitment by seabirds to ephemeral foraging foods. Ornis Scandinavica 23, 49-62.

Hastie, T., Tibshirani, R. J., 1990. Generalized Additive Models. Chapman and Hall, London.

Hatton, A. D., Turner, S. M., Malin, G., Liss, P. S., 1998. Dimethylsulphoxide and other biogenic sulphur compounds in the Galapagos Plume. Deep-Sea Research II 45, 1043 1053.

Hickey, B. M., 1998. Coastal oceanography of western North America from the tip of Baja California to Vancouver Island. In: Robinson, A.R., Brink, K.H. (Eds.), The Sea, volume 11. John Wiley \& Sons, New York NY, pp. 345-394.

Hoefer, C. J., 2000. Marine bird attraction to thermal fronts in the California Current System. Condor 102, 423-427.

Hoffman, W., Heinemann, D., Wiens, J. A., 1981. The ecology of seabird feeding flocks in Alaska. Auk 98, 437-456.

Hunt, G. L., Jr., 1991. Occurrence of polar seabirds in relation to prey concentrations and oceanographic factors. Polar Research 10, 553-559.

Hunt, G. L., Jr., Harrison, N. M., Cooney, R. T., 1990. The influence of hydrographic structure and prey abundance on foraging of Least Auklets. Studies in Avian Biology $14,7-22$.

Hunt, G. L., Jr., Piatt, J. F., Erikstad, K. E., 1991. How do foraging seabirds sample their environment? Proceedings of the International Ornithological Congress 20, 22722279.

Hunt, G. L., Jr., Russell, R. W., Coyle K. O., Weingartner T., 1998. Comparative foraging ecology of planktivorous auklets in relation to ocean physics and prey availability. Marine Ecology Progress Series 167, 241-259. 
Hunt, G. L., Jr., Mehlum, F., Russell, R. W., Irons, D., Decker, M. B., Becker, P. H., 1999. Physical processes, prey abundance, and the foraging ecology of seabirds. Proceedings of the International Ornithological Congress 22, 2040-2056.

Kleinbaum, D. G., Kupper, L. L., Muller, K. E., 1988. Applied Regression Analysis and other Multivariable Methods. PWS-KENT Publishing Company, Boston.

Kundu, P. K., Allen, J. S., 1976. Some three-dimensional characteristics of low frequency current fluctuations near the Oregon coast. Journal of Physical Oceanography 6, 181199.

Kwint, R. L. J., Kramer, K. J. M., 1995. Dimethylsulphide production by plankton communities. Marine Ecology Progress Series 121, 227-237.

Kwint, R. L. J., Kramer, K. J. M., 1996. Annual cycle of the production and fate of DMS and DMPS in a marine coastal system. Marine Ecology Progress Series 134, 217-224.

Lequette, B., Verheyden, C, Jouventin, P., 1989. Olfaction in subantarctic seabirds: its phylogenetic and ecological significance. Condor 91, 732-735.

Levasseur, M., Michaud, S., Egge, J., Cantin, G., Nejstgaard, J. C., Sanders, R., Fernandez, E., Solberg, P. T., Heimdal, B., Gosselin, M., 1996. Production of DMSP and DMS during a mesocosm study of an Emiliania huxleyi bloom: influence of bacteria and Calanus finmarchicus grazing. Marine Biology 126, 609-618.

Loggerwell, E. A., Hargraeves, N. B., 1996. The distribution of seabirds relative to their fish prey off Vancouver Island: opposing results at large and small spatial scales. Fisheries Oceanography 5, 163-175.

Maniscalco, J. M., Ostrand, W. D., Coyle, K. O., 1998. Selection of fish schools by flocking seabirds in Prince William Sound, Alaska. Colonial Waterbirds 21, 314-322.

Mantua, N. J., Hare, S. R., 2002. The Pacific Decadal Oscillation. Journal of Oceanography 58, 35-44.

Mehlum, F., Hunt, G. L., Jr., Lusek, Z., Decker, M. B., 1999. Scale-dependent correlations between the abundance of Brünnich's Guillemots and their prey. Journal of Animal Ecology 68, 60-72.

Montevecchi, W. A., 1993. Birds as indicators of changes in marine prey stocks. In: Furness, R.W., Greenwood, J. J. D. (Eds.), Birds as Monitors of Environmental Change. Chapman and Hall, London, pp 217-266.

Nevitt, G. A., 1999a. Olfactory foraging by Antarctic procellariiform seabirds: life at high Reynolds numbers. Biological Bulletin 198, 245-253.

Nevitt, G. A., 1999b. Olfactory foraging in Antarctic seabirds: a species-specific attraction to krill odors. Marine Ecology Progress Series 177, 235-241.

Nevitt, G. A., 1999c. Foraging by seabirds on an olfactory landscape. American Scientist $87,46-53$.

Nevitt, G. A., Veit, R. R., Kareiva, P. M., 1999. Dimethyl sulphide as a foraging cue for Antarctic procellariifrom seabirds. Nature 376, 680-682.

Oedekoven, C. S., Ainley, D. G., Spear, L.B., 2001. Variable responses of seabirds to change in marine climate: California Current, 1985-1994. Marine Ecology Progress Series 212, 265-281.

Peterson, W. T., Schwing, F. B., 2003. A new climate regime in northeast Pacific Ecosystems. Geophysical Research Letters, in press.

Pollard, R., 1986. Frontal surveys with a towed profiling conductivity/temperature/depth measurement package (SeaSoar). Nature 323, 433-435. 
Reid, J. L., Mantyla, A. W., 1976. The effect of geostrophic flow upon coastal sea elevations in the northern North Pacific Ocean. Journal of Geophysical Research 81, 3100-3110.

Roemmich, D., McGowan, J. A., 1995. Climatic warming and the decline of zooplankton in the California Current. Science 267, 1324-1326.

Russell, R. W., Hunt, G. L., 1992. Foraging in a fractal environment: spatial patterns in a marine predator-prey system. Journal of Landscape Ecology 7, 195-209.

Schneider, D. C., Duffy, D. C., 1985. Scale-dependent variability in seabird abundance. Marine Ecology Progress Series 25, 211-218.

Schneider, D. C., Piatt, J. F., 1986. Scale-dependent correlation of seabirds with schooling fish in a coastal ecosystem. Marine Ecology Progress Series 32, 237-246.

Schwing, F. B., Murphree, T., deWitt, L., Green, P. M., 2002. The evolution of oceanic and atmospheric anomalies in the northeast Pacific during the El Niño and La Niña events of 1995-2001. Progress in Oceanography 54, 459-491.

Seber, G. A. F., 1977. Linear regression analysis. John Wiley and Sons, New York.

Spear, L. B., Ainley, D. G. Hardesty, B. D. Howell, S. N. G., Webb S. W., ms. Reducing biases affecting at-sea surveys of seabirds: use of multiple observer teams. Marine Ornithology, in review.

Spear, L. B., Ballance, L. T., Ainley, D. G., 2001. Responses of seabirds to thermal boundaries in the tropical Pacific: the thermocline versus the Equatorial Front. Marine Ecology Progress Series 219, 275-289.

Spear, L., Nur, N., Ainley, D. G., 1992. Estimating absolute densities of flying seabirds using analyses of relative movement. Auk 109, 385-389.

Spear, L. B., Ainley, D. G., 1997a. Flight behaviour of seabirds in relation to wind direction and wing morphology. Ibis 139, 221-233.

Spear, L. B., Ainley, D. G., 1997b. Flight speed of seabirds in relation to wind speed and direction. Ibis 139, 234-251.

S-PLUS. 1997. S-PLUS 4 Guide to Statistics. Data Analysis Products Division, MathSoft, Seattle, WA.

STATA Corp, 1995. STATA Reference Manual: release $5.1,6^{\text {th }}$ ed. Stata Corporation, College Station, TX.

Swartzman, G., Hunt, G., 2000. Spatial association between murres (Uria spp.), puffins (Fratercula spp.) and fish shoals near Pribilof Islands, Alaska. Marine Ecology Progress Series 206, 297-309.

Tyler, W. B., Briggs, K. T., Lewis, D. B., Ford, R. G., 1993. Seabird distribution and abundance in relation to oceanographic processes in the California Current System. In: Vermeer, K., Briggs, K. T., Morgan, K. H., Siegel-Causey, D. (Eds.), The Status, Ecology, and Conservation of Marine Birds of the North Pacific. Special Publication, Canadian Wildlife Service, Ottawa, pp. 48-60.

Tynan, C. T., Ainley, D. G., Barth, J. A., Cowles, T. J., Pierce, S. D., Spear, L. B., in press. Cetacean distributions relative to ocean processes in the northern California Current System. Deep-sea Research II, this volume.

Veit, R. R., McGowan, J. A., Ainley, D. G., Wahl T. R., Pyle P., 1997. Apex marine predator declines $90 \%$ in association with changing oceanic climate. Global Change Biology 3, 23-28. 
Wallraff, H. G., 2004. Avian olfactory navigation: its empirical foundation and conceptual state. Animal Behaviour 67, 189-204.

Wanless, S., Harris, M. P., Morris, J. A., 1990. A comparison of feeding areas used by individual Common Murres (Uria aalge), Razorbills (Alca torda) and an Atlantic Puffin (Fratercula arctica) during the breeding season. Colonial Waterbirds 13, 16-24.

Warham, J., 1990. The petrels — their ecology and breeding systems. Academic Press, London.

Wiens, J. A, Scott, J. M., 1976. Model estimation of energy flow in Oregon coastal seabird populations. Condor 77, 439-452. 


\section{FIGURE CAPTIONS}

Fig.1. Top panel. Cruise tracks in the northern portion of the California Current, MayJune and July-August 2000, relative to chlorophyll concentration at 5 meters. Cruise track segments shown by black stars include both seabird and SeaSoar/bioacoustic coverage; those that included just seabird surveys are shown by white stars (used only in calculations of bird abundance).

Bottom panel. The correspondence of Sooty Shearwaters with acoustic backscatter at $200 \mathrm{kHz}$. Triangles represent shearwater abundance, with each triangle representing the average of three consecutive transects. The height and width of the triangles are proportional to the natural log of the densities. The largest triangle during both time periods represents 1250 shearwaters $\mathrm{km}^{-2}$.

Fig. 2A. The correspondence of Sooty Shearwater abundance with various upwellingdriven features defined by sea-surface temperature gradient (A) and/or dynamic height $(\mathrm{B}, \mathrm{C})$. Geopotential anomaly is calculated for $5 \mathrm{~m}$ depth relative to $100 \mathrm{~m}$. Feature $\mathrm{A}$ is located along the blue-to-green boundary (ca $11.5^{\circ} \mathrm{C}$ in June, $12^{\circ} \mathrm{C}$ in August); Feature $\mathrm{C}$ is the double heavy line, representing $2.35 \mathrm{~m}^{2} \mathrm{~s}^{-2}$, the center of the upwelling jet; and Feature B is the first single heavy line inshore of C, representing $2.0 \mathrm{~m}^{2} \mathrm{~s}^{-2}$, marking the upper edge of a steep, inshore gradient in dynamic height. Symbols represent bird abundance, with each representing the average of three consecutive transects. The height and width of symbols are proportional to the natural log of the densities. The largest triangle regardless of period represents 1250 shearwaters $\mathrm{km}^{-2}$.

B. The correspondence of Common Murre abundance with various upwelling-driven features, defined as above. The largest square represents 669 murres $\mathrm{km}^{-2}$.

C. The correspondence of Cassin's Auklet abundance with various upwelling-driven features, defined as above. The largest diamond represents 310 auklets $\mathrm{km}^{-2}$.

Fig. 3. The change in the biomass of seabirds $\left(\mathrm{kg} / \mathrm{km}^{2}\right)$ observed along GLOBEC-NEP line $7\left(43.2^{\circ} \mathrm{N}\right)$ in relation to sea-surface temperature, 1 June 2000 . The correspondence between bird concentrations and the cooler, inshore water of the along-shore Feature $\mathrm{A}$ (steep gradient in vicinity of $11^{\circ} \mathrm{C}$ ) is clear.

Fig. 4. Densities (birds $\mathrm{km}^{-2}$ ) of 11 seabird species relative to distance to the front/feature with which each was statistically associated (Table 4; Fork-tailed Storm-Petrel not associated with any fronts). Shown are the means (dots) and standard errors (vertical bars). Negative distance denotes density on the west (offshore) side of a given feature, positive denotes density on the east (inshore) side. Numbers adjacent to means are sample sizes (number of 15-min transects). Sample sizes for a given feature were the same for each species associated with it.

Fig. 5. PCA analysis that compares habitat use by 12 species of seabirds in the northern California Current. Species enclosed in the same circle were not significantly different in habitat affinity (Sidak multiple comparison tests, all $\mathrm{P}>0.05$ ). See Table 2 for species codes. 
Table 1

Pearson linear correlation coefficients $(r)$ among physical and biological environmental variables $^{\mathrm{a}} ; n=554$ survey transects, upwelling period 2000 .

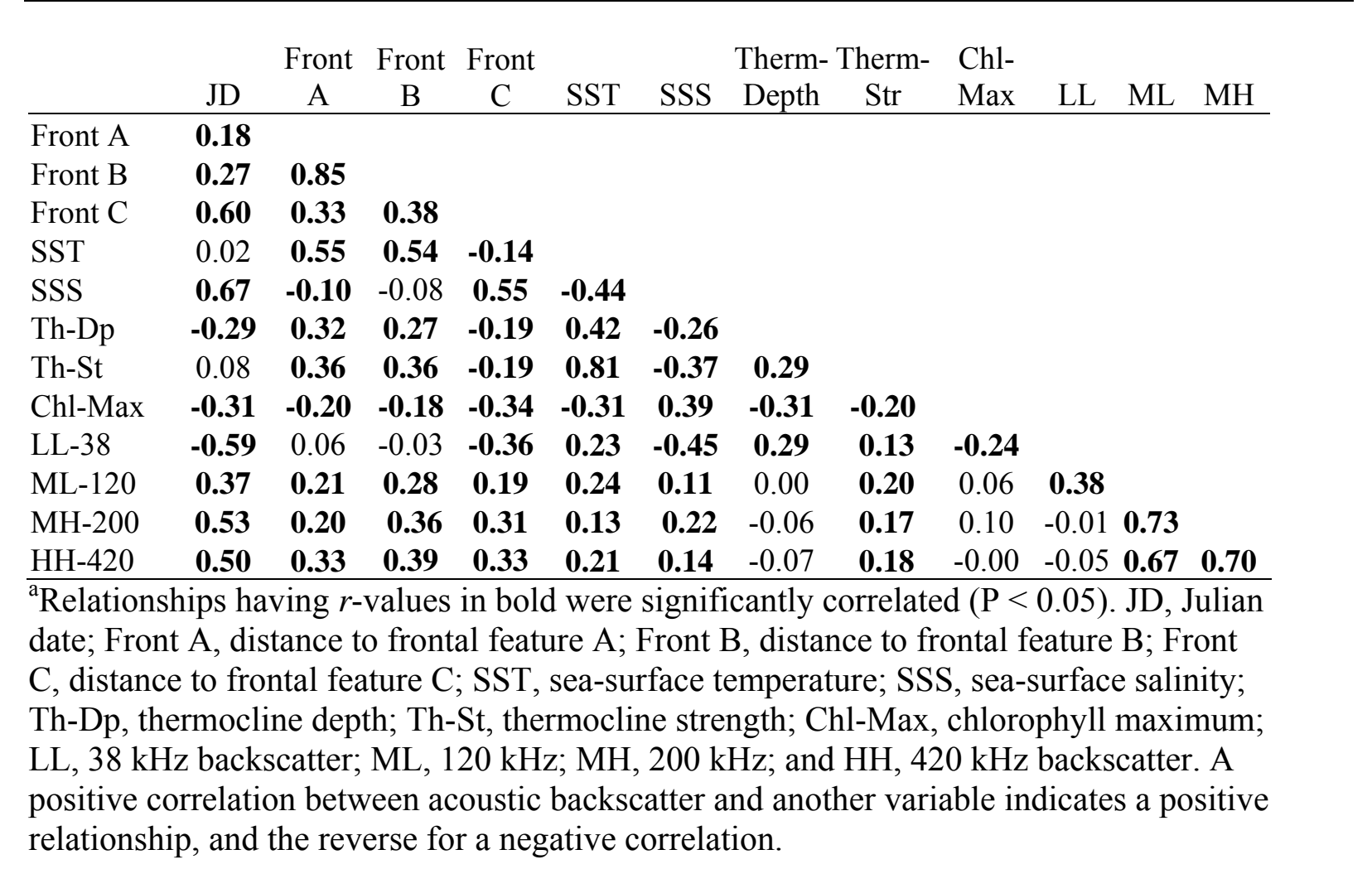


Table 2

The 12 most abundant seabird species recorded during GLOBEC surveys in summer 2000.

\begin{tabular}{|c|c|c|c|c|}
\hline Species & $\begin{array}{l}\text { Raw } \\
\text { Count }\end{array}$ & $\begin{array}{l}\text { Adjusted } \\
\text { Count }\end{array}$ & $\begin{array}{l}\text { Composition } \\
\text { by Number, } \\
\%\end{array}$ & $\begin{array}{l}\text { Composition } \\
\text { by Mass, } \\
\%\end{array}$ \\
\hline $\begin{array}{l}\text { Sooty Shearwater Puffinus griseus } \\
\text { (SHSO) }\end{array}$ & 15,138 & $17,446.9$ & 56.9 & 59.4 \\
\hline $\begin{array}{l}\text { Common Murre Uria aalge } \\
\text { (MUCO) }\end{array}$ & 4,982 & $5,370.6$ & 17.5 & 24.3 \\
\hline $\begin{array}{l}\text { Cassin's Auklet Ptychoramphus aleuticus } \\
\text { (AKCA) }\end{array}$ & 2,426 & $2,421.8$ & 7.9 & 1.9 \\
\hline $\begin{array}{l}\text { Northern Phalarope Phalaropus lobatus } \\
\text { (PHRN) }\end{array}$ & 1,515 & $1,492.5$ & 4.9 & 0.3 \\
\hline $\begin{array}{l}\text { Fork-tailed Storm-Petrel Oceanodroma } \\
\text { furcata (STFT) }\end{array}$ & 892 & 894.8 & 2.9 & 0.2 \\
\hline $\begin{array}{l}\text { Leach's Storm-Petrel O. leucorhoa } \\
\text { (STLE) }\end{array}$ & 725 & 853.1 & 2.8 & 0.2 \\
\hline $\begin{array}{l}\text { Black-footed Albatross Phoebastria } \\
\text { nigripenis (ALBF) }\end{array}$ & 469 & 494.7 & 1.6 & 9.0 \\
\hline $\begin{array}{l}\text { Northern Fulmar Fulmarus glacialis } \\
\text { (FUNO) }\end{array}$ & 507 & 426.3 & 1.4 & 1.4 \\
\hline $\begin{array}{l}\text { Red Phalarope Phalaropus fulicarius } \\
\text { (PHRE) }\end{array}$ & 362 & 353.6 & 1.2 & 1.2 \\
\hline $\begin{array}{l}\text { Pink-footed Shearwater Puffinus } \\
\text { creatopus (SHPF) }\end{array}$ & 383 & 345.6 & 1.1 & 1.0 \\
\hline $\begin{array}{l}\text { Western Gull Larus occidentalis } \\
\text { (GUWE) }\end{array}$ & 231 & 201.3 & 0.7 & 0.9 \\
\hline $\begin{array}{l}\text { Rhinoceros Auklet Cerorhinca } \\
\text { monocerata (AKRH) } \\
\text { Total }\end{array}$ & $\begin{array}{r}153 \\
27,783\end{array}$ & $\begin{array}{r}144.8 \\
30,446.9\end{array}$ & $\begin{array}{r}0.5 \\
99.2\end{array}$ & $\begin{array}{c}0.3 \\
100.1\end{array}$ \\
\hline
\end{tabular}

Adjusted count is the birds observed corrected for the effects of bird movement relative to that of the ship (details in Methods). Species are presented in order of abundance. 
Table 3

Estimates of population size (with $95 \%$ confidence interval [95\% CI], coefficient of variation [CV]) for the 12 most abundant species of seabirds during surveys in May-June and July-August 2000

\begin{tabular}{|c|c|c|c|c|c|c|}
\hline \multirow[t]{2}{*}{ Species } & \multicolumn{2}{|c|}{ Population size } & \multicolumn{2}{|c|}{$95 \% \mathrm{CI}$} & \multicolumn{2}{|c|}{$\mathrm{CV}$} \\
\hline & May & August & May & August & May & August \\
\hline \multicolumn{7}{|l|}{ Sooty } \\
\hline Shearwater & 475,200 & 63,200 & $389,300-670,300$ & $48,700-79,700$ & 12.3 & 11.5 \\
\hline \multicolumn{7}{|l|}{ Common } \\
\hline Murre & 147,500 & 82,100 & $120,200-189,200$ & $66,500-97,100$ & 11.5 & 10.0 \\
\hline \multicolumn{7}{|l|}{ Cassin’s } \\
\hline Auklet & 11,800 & 87,600 & $9,600-16,300$ & $62,500-105,200$ & 14.8 & 11.3 \\
\hline \multicolumn{7}{|l|}{ Red-necked } \\
\hline Phalarope & 0 & 52,900 & 0 & $42,500-75,100$ & ---- & 15.6 \\
\hline \multicolumn{7}{|l|}{ Fork-tailed } \\
\hline Storm-Petrel & 42,500 & 16,500 & $32,700-49,300$ & $12,600-20,900$ & 12.0 & 13.4 \\
\hline \multicolumn{7}{|l|}{ Leach’s } \\
\hline Storm-Petrel & 30,400 & 20,400 & $24,500-38,200$ & $14,600-25,000$ & 11.1 & 13.4 \\
\hline \multicolumn{7}{|l|}{ Black-footed } \\
\hline Albatross & 22,600 & 3,800 & $14,200-29,300$ & $2,300-4,900$ & 18.8 & 17.0 \\
\hline \multicolumn{7}{|l|}{ Northern } \\
\hline Fulmar & 230 & 20,600 & $150-320$ & $17,600-25,600$ & 18.4 & 9.8 \\
\hline Red Phalarope & 540 & 9,100 & $310-760$ & $5,300-12,200$ & 20.5 & 23.0 \\
\hline \multicolumn{7}{|l|}{ Pink-footed } \\
\hline Shearwater & 2,400 & 15,500 & $1,500-2,900$ & $12,100-19,200$ & 15.1 & 11.5 \\
\hline Western Gull & 5,600 & 4,500 & $4,600-7,400$ & $2,500-7,100$ & 13.5 & 20.8 \\
\hline \multicolumn{7}{|l|}{ Rhinoceros } \\
\hline Auklet & 6,300 & 1,900 & $5,100-7,900$ & $870-2,470$ & 11.2 & 17.9 \\
\hline TOTAL & 745,100 & 378,100 & & & & \\
\hline
\end{tabular}


Table 4

Results of multiple regression models to determine the relationship between species' density with physical and biological environmental variables ${ }^{\mathrm{a}}$. Variables grouped as temporal (1), geographic (4), physical (5), and biological (5). See Table 2 for species' codes.

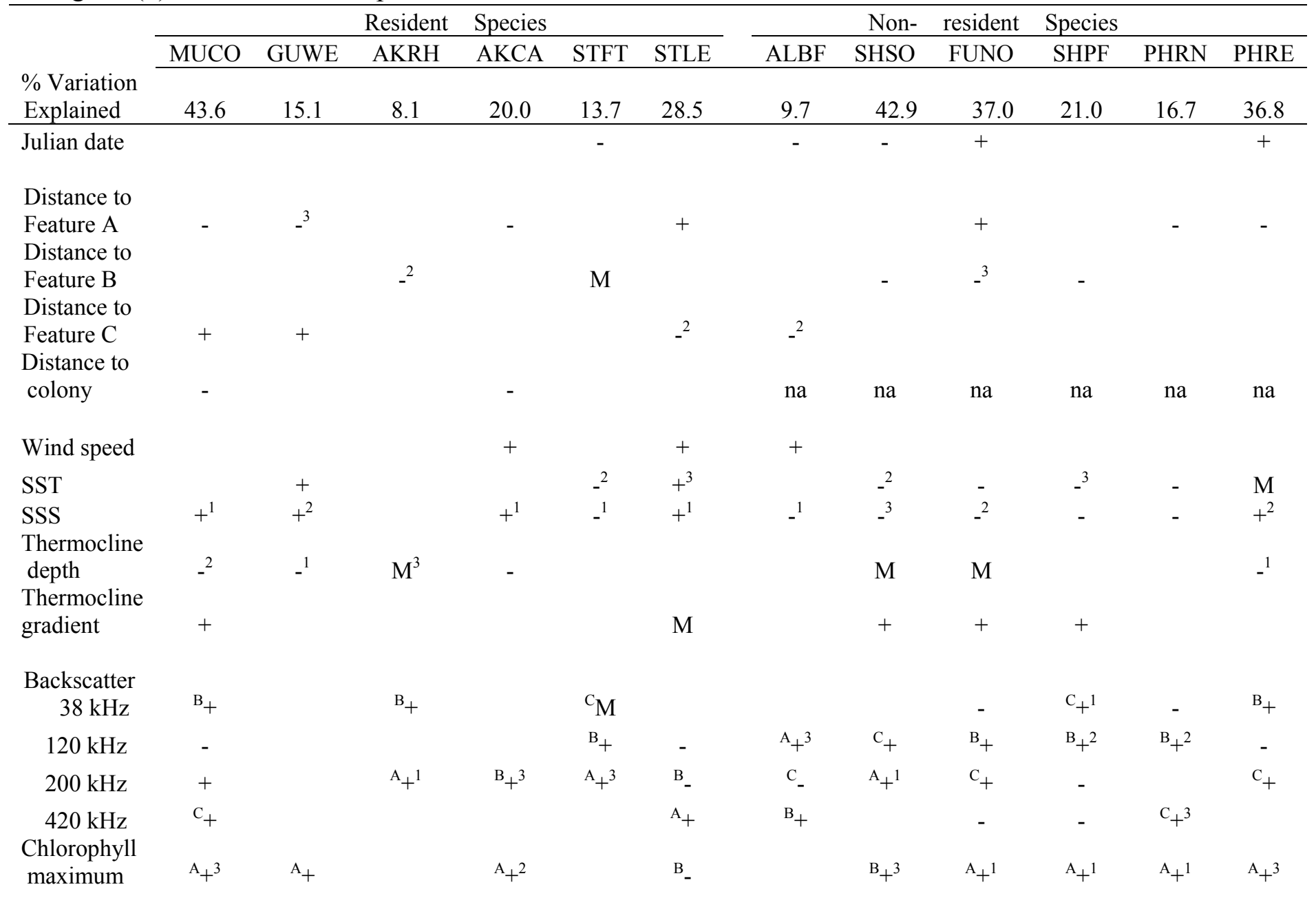


No. Signif

Variables $^{b}$ 12

6 4 $9 \quad 7 \quad 10$ 6 $8 \quad 12$

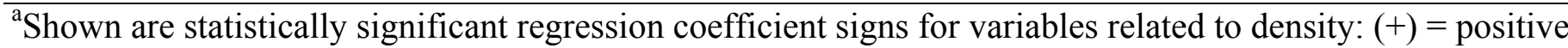
response of density to increase in a variable; $(-)=$ negative response, and " $\mathrm{M}$ " = curvilinear response where a significant linear effect was not observed. Details on curvilinear effects are not presented if there was a significant linear relation. Superscripts $(1,2,3)$ denote the first-, second-, or third-most important variables in explaining variation in bird density; superscripts (A, B, C) indicate that the variable explained the first-, second, or third-greatest amount of variance among the six biological variables (bioacoustic and chlorophyll $a$ variables). A positive coefficient for seabird response to $\mathrm{kHz}$ backscatter readings indicates that the species showed a positive response to higher densities of the prey described by that backscatter frequency in the water column. $\mathrm{Na}=$ not applicable.

${ }^{\mathrm{b}}$ Julian date not considered in count of significant environmental variables. 


\section{Table 5}

Results of principal components analyses (PCA), including eigenvector (cumulative) proportions of variance explained by the eight environmental variables most important in explaining distributions of the 12 seabird species in the northern California Current (see Results; multiple regression analyses).

\begin{tabular}{lclcr}
\hline & Eigenvalue & Environmental & \multicolumn{2}{c}{ Eigenvector loading } \\
PC & Cumulative proportion & variable & PC1 & PC2 \\
\hline 1 & 0.34 & Front A & -0.49 & -0.29 \\
2 & 0.60 & Front B & -0.55 & -0.20 \\
3 & 0.79 & Sea-surface salinity & -0.09 & 0.58 \\
4 & 0.88 & Chlorophyll maxium & -0.08 & 0.48 \\
5 & 0.94 & 38 khz backscatter & 0.01 & -0.52 \\
6. & 0.97 & 120 khz backscatter & 0.39 & -0.06 \\
7. & 0.99 & 200 khz backscatter & 0.43 & 0.17 \\
8. & 1.00 & 420 khz backscater & 0.41 & 0.05 \\
\hline
\end{tabular}


Figure 1

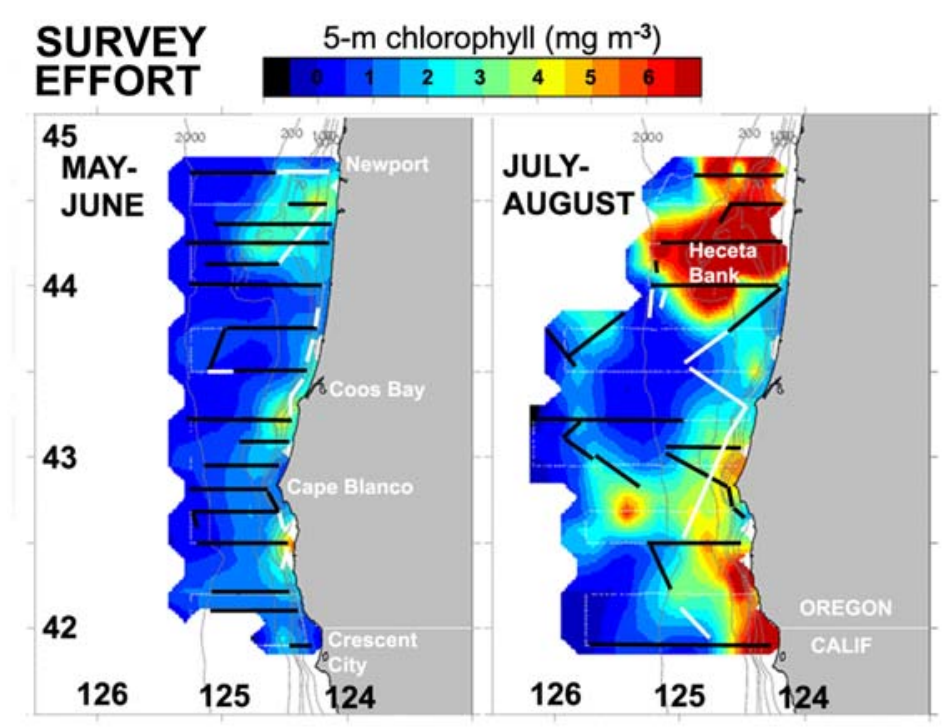

ACOUSTIC BACKSCATTER

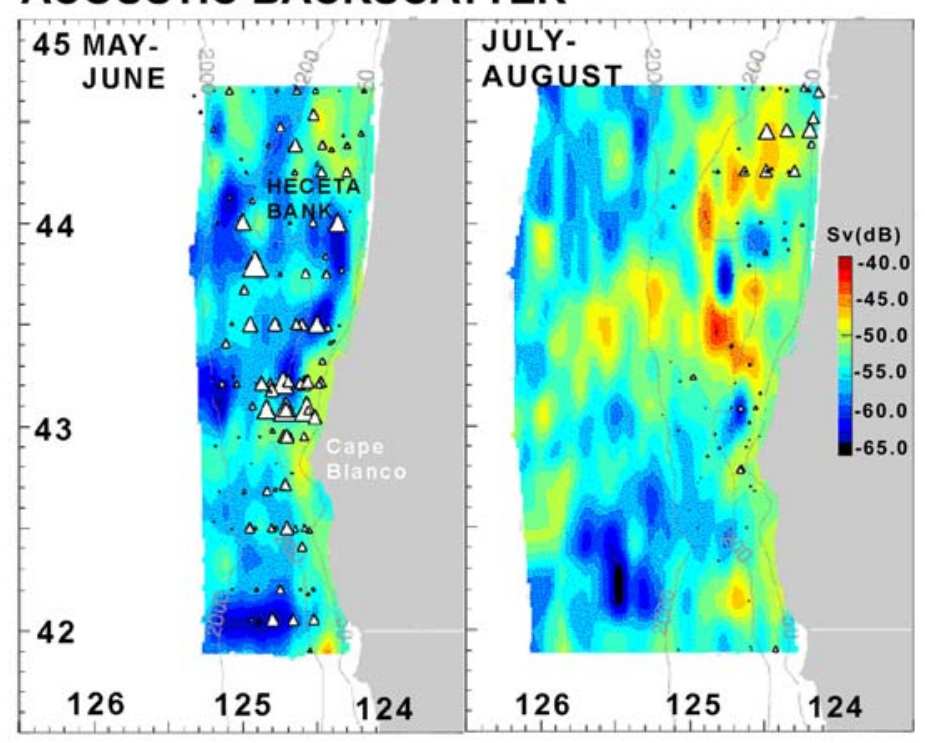


Fig. 2
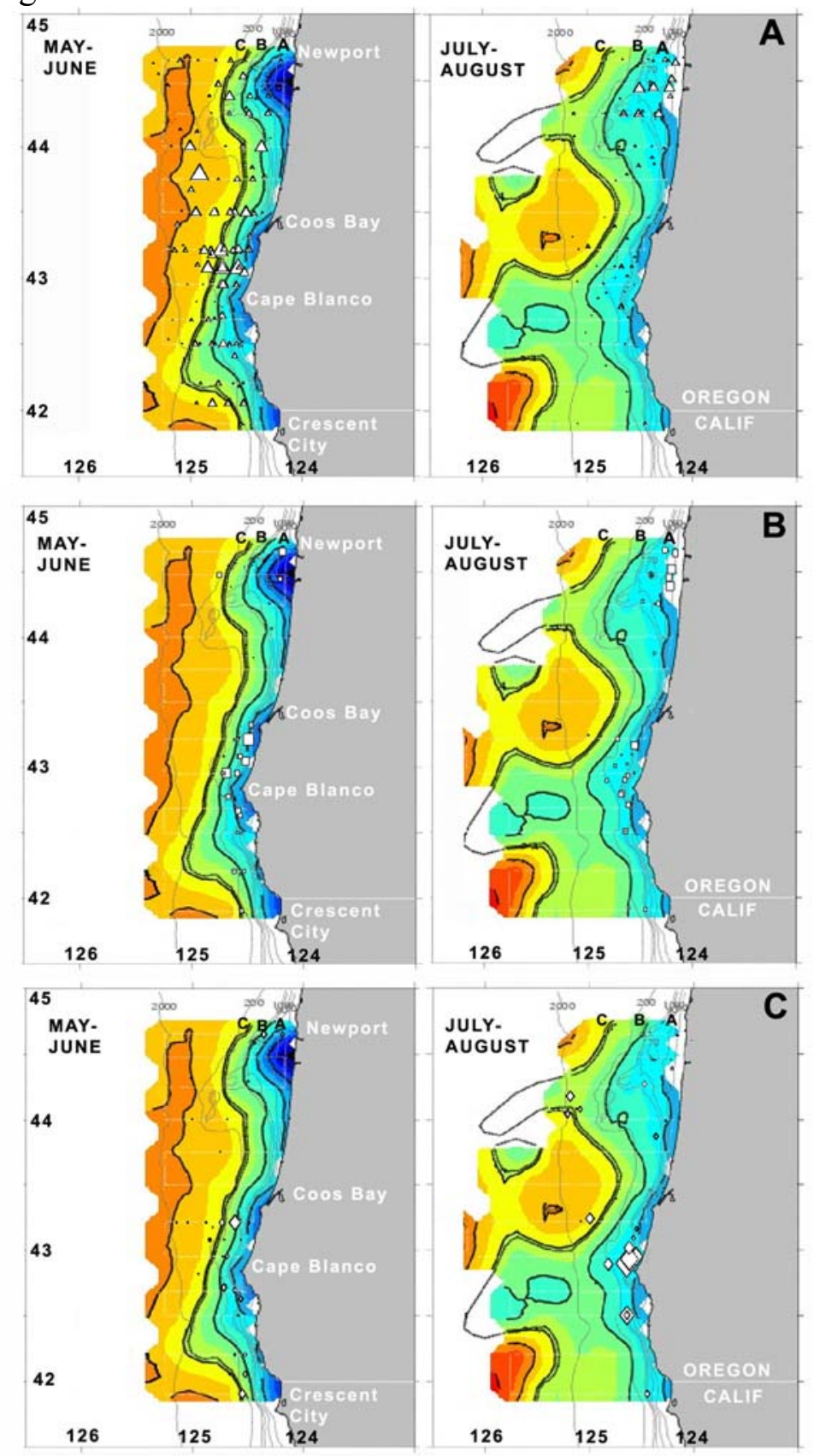
Fig. 3.

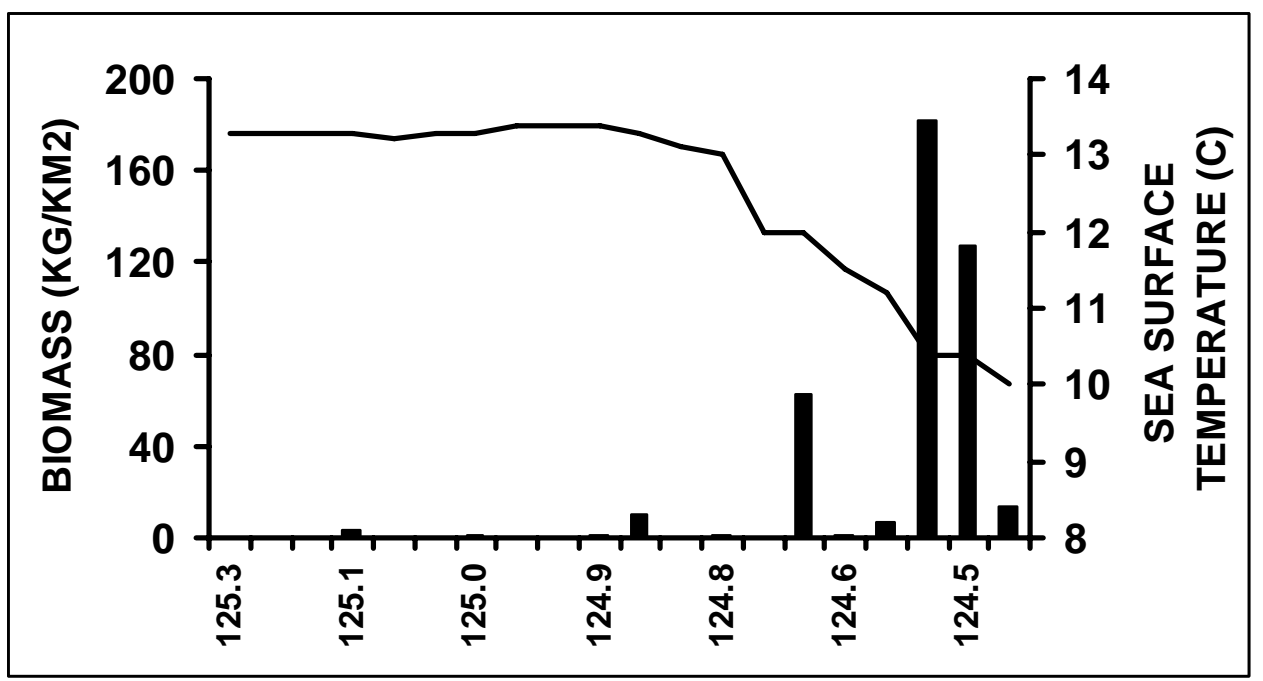


Fig. 4.
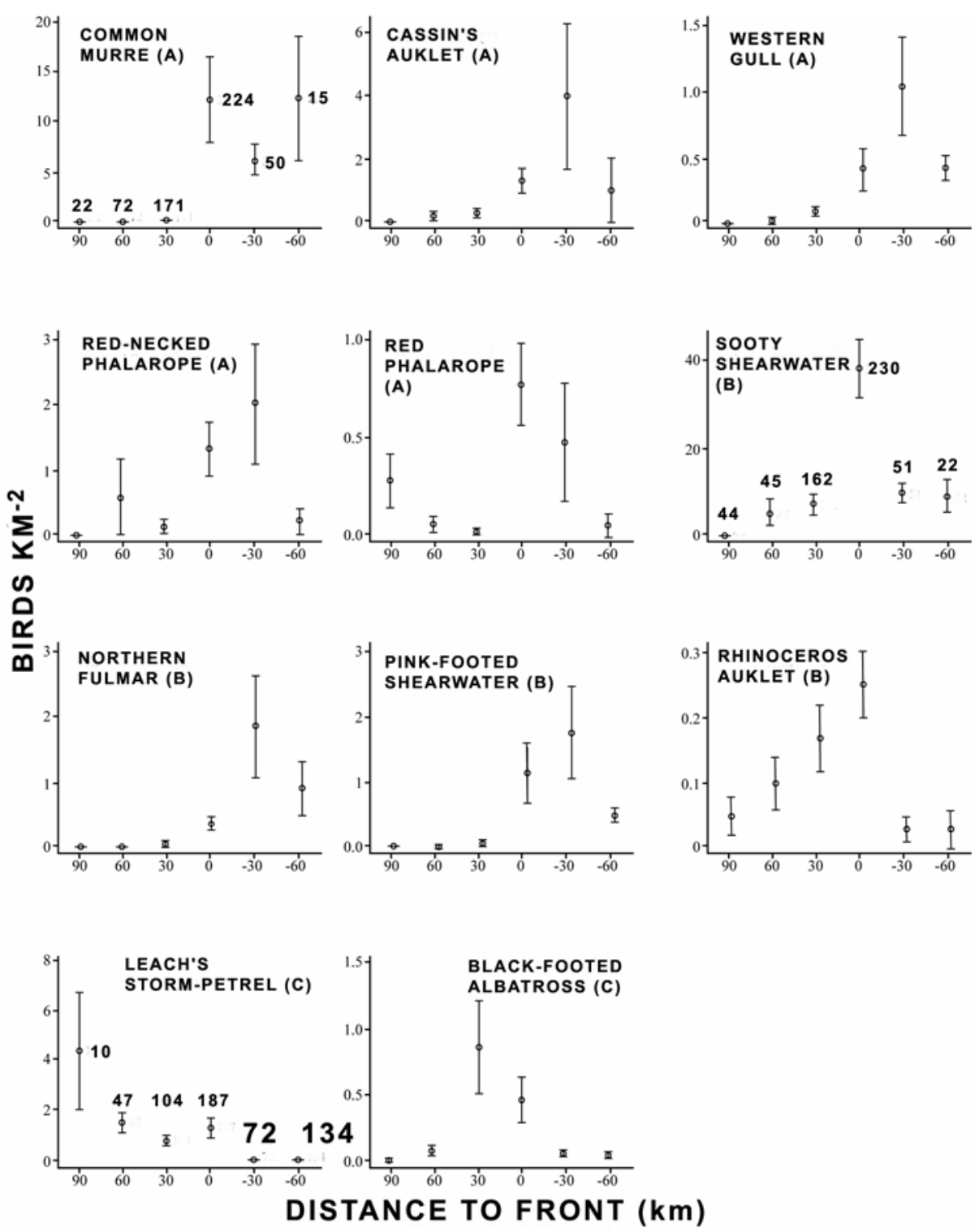
Fig. 5.

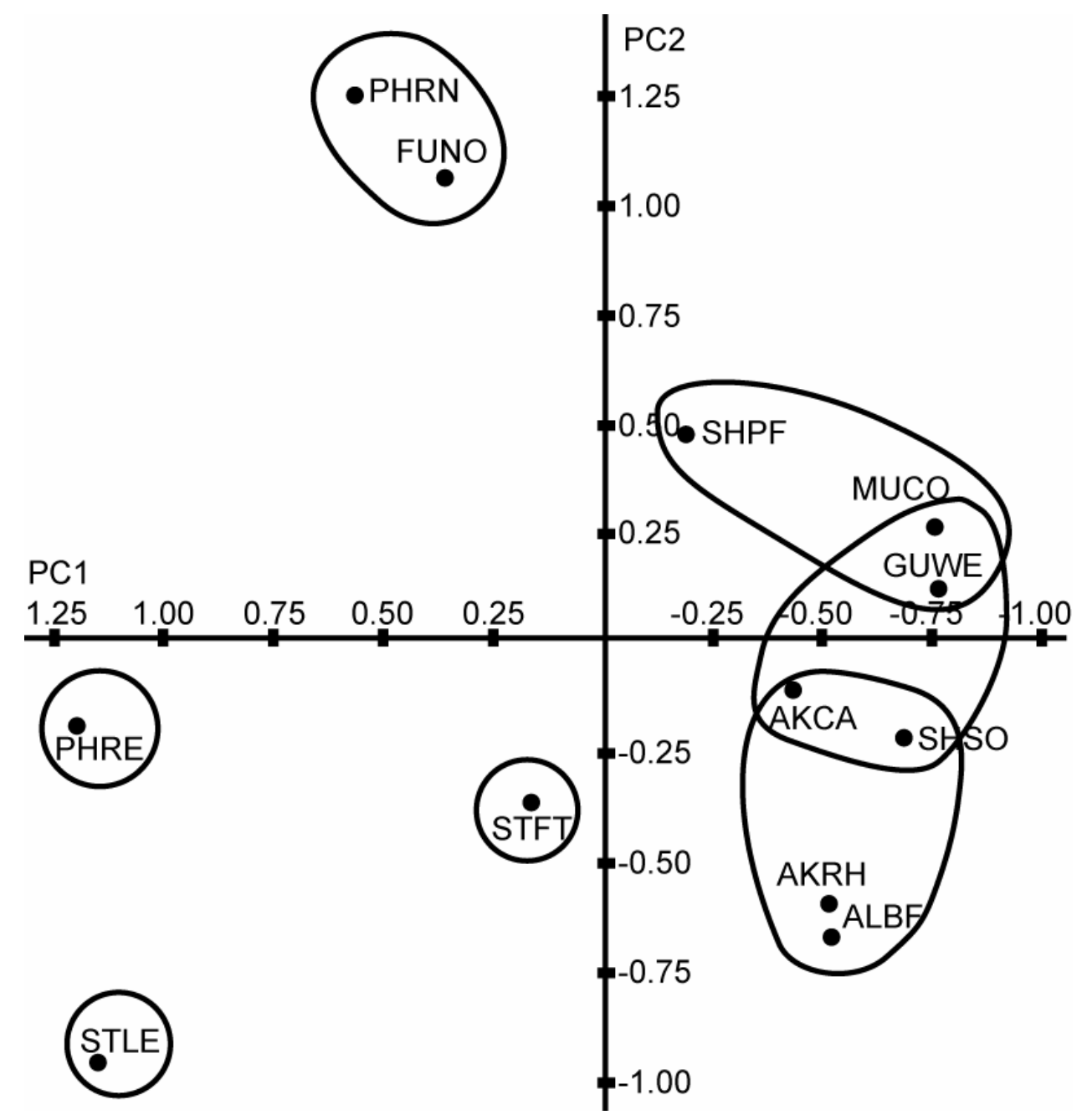

